\title{
Possibilities for the Use of Wood Ashes in Agriculture
}

\author{
Barbara Symanowicz ${ }^{*}$, Marcin Becher' ${ }^{1}$ Dawid Jaremko', Korneliusz Skwarek² \\ 1 Siedlce University of Natural Sciences and Humanities, Faculty of Natural Science, Agronomy Institute, Soil \\ Science and Plant Nutrition Department, Prusa 14, 08-110 Siedlce, Poland \\ 2 Doctoral studies, Siedlce University of Natural Sciences and Humanities, Faculty of Natural Science, Poland \\ * Corresponding author's e-mail: barbara.symanowicz@uph.edu.pl
}

\begin{abstract}
The aim of the study was to determine the agricultural usefulness of the ashes obtained following the combustion of wood of fourteen tree species (pear tree, apple tree, aspen, ash, alder, birch, poplar, hornbeam, pine, common walnut, oak, hazel, bird cherry and spruce) in home fireplaces. The following physical properties of the ashes were determined: colour, solubility, porosity, absorbability, compression strength, degree of fineness, moisture content and spreadability. In the ashes obtained from the combustion of wood in a fireplace furnace, the following parameters were determined: $\mathrm{pH}_{\mathrm{H} 2 \mathrm{O}}, \mathrm{pH}_{\mathrm{KCl}}\left(1\right.$ mole $\left.\mathrm{dm}^{-3} \mathrm{KCl}\right), \mathrm{pH}_{\mathrm{CaCl} 2}\left(0.01\right.$ mole $\left.\mathrm{dm}^{-3} \mathrm{CaCl}_{2}\right)$ and total alkalinity in terms of the suitability of ashes as a liming agent. The contents of $\mathrm{C}_{\text {tot. }}$ and $\mathrm{N}_{\text {tot. }}$ were determined with a CHNS/O elemental analyser by Perkin-Elmer and the contents of other elements (macronutrients and heavy metals) were specified using the method of atomic emission spectrometry with inductively coupled plasma ICP-AES. Wood ashes are a source of macronutrients for plants. Their contents can be presented in the following series of decreasing values: $\mathrm{Ca}>\mathrm{C}>\mathrm{K}>\mathrm{Mg}>\mathrm{P}>\mathrm{S}>\mathrm{N}$. Out of $1 \mathrm{t}$ of wood ash, approx. $160 \mathrm{~kg} \mathrm{C}, 6 \mathrm{~kg} \mathrm{~N}, 20 \mathrm{~kg} \mathrm{P}, 98 \mathrm{~kg} \mathrm{~K}, 302 \mathrm{~kg} \mathrm{Ca}$, $39 \mathrm{~kg} \mathrm{Mg}$ and $18 \mathrm{~kg} \mathrm{~S}$ can be introduced into the soil. The content of heavy metals in the analysed ashes was low, and exceeded the acceptable standards for their content in waste materials intended for liming soils. The analysed ashes exhibit good physical and chemical properties. They can be suitable for use in agriculture as a liming agent to be applied on medium and heavy soils.
\end{abstract}

Keywords: wood ashes, $\mathrm{pH}$, total alkalinity, macronutrients, heavy metals

\section{INTRODUCTION}

The concerns about the condition of natural environment have contributed to an increased interest in the renewable energy sources. The demand for alternative energy is an inevitable consequence of the economic development [Kalembasa et al. 2003] and fossil fuels will eventually be replaced by renewable energy sources, out of which the raw materials produced in the agricultural sector have aroused the greatest expectations [Meller, Bilenda 2013]. An increase in the use of wood and wastes obtained from wood processing, originating from rural areas, is one of the ways to gradually increase the share of energy from renewable resources [Wrzosek, Gworek 2010]. Wood ash is a waste product obtained from the combustion of wood [Kajda-Szcześniak 2014, Regulation...2014]. In agriculture, plant ashes are frequently used as mineral fertilisers. The ashes which are regarded as the most valuable are those obtained from the combustion of deciduous tree wood. The fertilisation value of ash depends on the type of combusted material and the type of wood [Ciesielczuk et al. 2011]. The physical and chemical properties of ashes lead to the improvement of the structure of heavy soils and the fertiliser components contained in them are easily absorbed by plants [PN-EN 2004, Regulation...2004].

Ashes contain significant amounts of basic oxides [Symanowicz, Kalembasa 2004, 2005] which deacidify the soil [Arvidsson, Lundkvist 2003, Ciesielczuk et al. 2011]. A study carried out by Meller, Bilenda [2012, 2013], KowalczykJuśko [2017] and Piekarczyk et al. [2017] indicated an increase in alkalinity, and in the level of macro- and micronutrients in the soil, following 
the application of ashes from biomass. Given the high contents of potassium, phosphorus and micronutrients, ash can also be used as a potassiumphosphorus fertiliser [Kalembasa 2006, KabataPendias 2011]. Baran et al. [2015] indicated the possibility for using the ash from heat and power stations for composting sewage sludge and the obtained composts for soil reclamation.

The issues concerning wood ashes are still valid, as rural inhabitants continue to use firewood to a large extent. If we assume that 1.5 million families combust wood, and that each of them can accumulate approx. $100 \mathrm{~kg}$ ash annually, the amount of this fertiliser will be 150 thousand tonnes, containing 8.3 thousand tonnes $\mathrm{K}$ and 1,100 tonnes P [Statistical yearbook 2015]. The results of analyses pertaining to wood ashes indicate low levels of heavy metals (cadmium, lead, zinc, copper, chromium and nickel), which prevents the contamination of the soil and plants [Regulation...2002, 2008, 2010, 2013].

The aim of the study was to determine the agricultural usefulness of ashes obtained following the combustion of wood of fourteen tree species (pear tree, apple tree, aspen, ash, alder, birch, poplar, hornbeam, pine, common walnut, oak, hazel, bird cherry and spruce) in home fireplaces.

\section{MATERIAL AND METHODS}

In order to assess the fertiliser value of wood ashes, fourteen ashes obtained from the combustion of wood in a fireplace furnace were analysed. The ashes obtained from the combustion of pear tree, apple tree, aspen, ash, alder, birch, poplar, hornbeam, pine, common walnut, oak, hazel, bird cherry and spruce were used.

a)

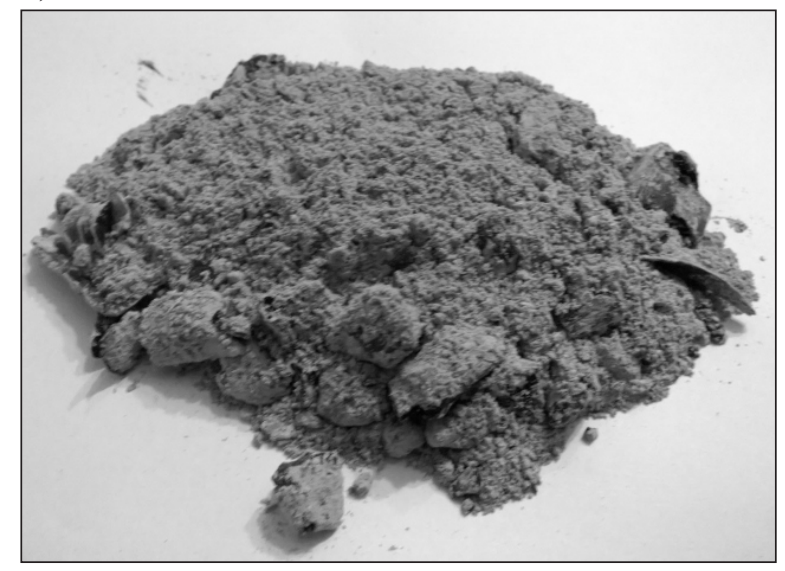

The following physical properties of the ashes were determined: colour, solubility, porosity, absorbability, compression strength, degree of fineness, moisture content and spreadability.

In order to determine the amount of ash in particular types of wood, mineralisation was carried out at $600^{\circ} \mathrm{C}$ for three hours in a muffle furnace and then further combustion was carried out at the same temperature for another hour [Xiao et al. 2011]. In the ashes obtained from the combustion of wood in a fireplace furnace, the following were determined: $\mathrm{pH}_{\mathrm{H} 2 \mathrm{O}}, \mathrm{pH}_{\mathrm{KCl}}\left(1\right.$ mole $\mathrm{dm}^{-3}$ $\mathrm{KCl}), \mathrm{pH}_{\mathrm{CaCl} 2}\left(0.01\right.$ mole $\left.\mathrm{dm}^{-3} \mathrm{CaCl}_{2}\right)$ and total alkalinity in terms of the suitability of ashes as a liming agent. The contents of $\mathrm{C}_{\text {tot. }}$ and $\mathrm{N}_{\text {tot. }}$ were determined with a CHNS/O elemental analyser by Perkin-Elmer and the contents of other elements (macronutrients and heavy metals) were specified using the method of atomic emission spectrometry with inductively coupled plasma (ICP-AES). Different colours of the ashes obtained following the combustion are presented in Figure 1.

The data on the content of ashes, macronutrients and heavy metals were compared statistically using the Statistica software, Ver. 12, StatSoft 2017.

\section{RESULTS AND DISCUSSION}

The analysed ashes had different colours, from ashen to grey and light-brown. They were characterised by good solubility as well as high porosity and absorbability. The wood ashes obtained from the combustion of wood in a home fireplace exhibited a complete lack of compression strength and dispersed in water. The degree of fineness of the ashes varied due to incomplete combustion of wood. Most ashes were character-

b)

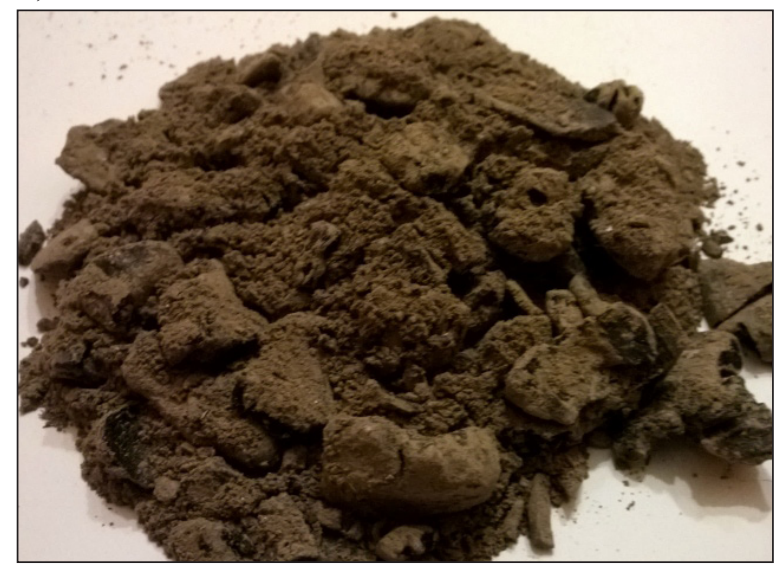

Figure 1. Wood ashes: a - alder, b - birch (photo: B. Symanowicz) 
ised by a fine fraction with a granulometric composition of ordinary dust (ord. dst), and a very low moisture content. The above-mentioned features indicate the possibility for the application of ash on soils in windless weather.

Low ash content (0.31-1.53\%), compared to ashes from brown coal [Xiao et al. 2011] and ashes from triticale straw [Ciesielczuk et al. 2011], indicates its usefulness in agriculture.

The $\mathrm{pH}$ value of the ashes under analysis was defined as strongly alkaline, based on the $\mathrm{pH}$ determined in distilled water, in mole $\mathrm{dm}^{-3} \mathrm{KCl}$ and in $0.01 \mathrm{~mole} \cdot \mathrm{dm}^{-3} \mathrm{CaCl}_{2}$ (Table 1). As reported by Arvidsson, Lunkvist [2003], wood ash alkalises the soil and increases both the exchange capacity and the degree of saturation with alkaline cations. The determined $\mathrm{pH}$ value of the ashes was approx. 1.5 times higher than that of typical calcium and calcium-magnesium fertilisers and of the ash following the combustion of hard coal [Antonkiewicz 2014]. The total alkalinity of wood ashes ranged from 38.7 to $53.7 \%$ as a total of $\mathrm{CaO}$ and $\mathrm{MgO}$. When deciding on the use of these ashes for soil deacidification, it should be borne in mind that calcium and magnesium are present in the oxide (fast-acting) form. They can be applied on medium and heavy soils. Given the rapid reaction with the soil, small doses of approx. $1 \mathrm{t}$. $\mathrm{ha}^{-1}$ should be applied during each treatment. The ashes obtained following the combustion of ash, poplar, hornbeam and common walnut do not meet the requirements (they contain below 54\%
$\mathrm{CaO}+\mathrm{MgO}$ and cannot be used in agriculture). However, Kowalczyk-Juśko [2009], analysed the ash obtained from various energy plants and identified the total alkaline compounds $\left(\mathrm{Fe}_{2} \mathrm{O}_{3}\right.$, $\mathrm{CaO}, \mathrm{MgO}, \mathrm{Na}_{2} \mathrm{O}, \mathrm{K}_{2} \mathrm{O}$, and $\mathrm{P}_{2} \mathrm{O}_{5}$ ). Wacławowicz [2011] studied the use of ashes from the combustion of biomass (including oak wood) in agriculture, and found a positive effect on the decrease in the amount of toxic exchangeable aluminium. The ash originating from furnaces with a granulometric composition of ordinary dust, obtained from the combustion of hard coal and used in a study by Antonkiewicz and Wiśniowska-Kielian [2014], was characterised by worse parameters of chemical composition compared to wood ashes.

The analysed ashes were characterised by a large amount of total carbon (Table 2), including carbon in organic compounds remaining after the incomplete combustion of wood. This can have a favourable effect on improving the physical properties of soil. Coal will also eliminate the negative effect of fast-acting ashes on changing the soil structure. The determined amounts of nitrogen in ashes were at a level similar to the values obtained in other studies, which also analysed willow chips [Kalembasa et al. 2003]. Significant levels of phosphorus, potassium, calcium, magnesium and sulphur should be regarded as a potential source of these ingredients for plants. Out of $1 \mathrm{t}$ of wood ash, approx. $160 \mathrm{~kg} \mathrm{C}, 6 \mathrm{~kg} \mathrm{~N}, 20$ $\mathrm{kg} \mathrm{P}, 98 \mathrm{~kg} \mathrm{~K}, 302 \mathrm{~kg} \mathrm{Ca}, 39 \mathrm{~kg} \mathrm{Mg}$ and $18 \mathrm{~kg}$ $\mathrm{S}$ can be introduced into the soil. The ash used

Table 1. Selected properties of wooden ashes

\begin{tabular}{|l|c|c|c|c|c|}
\hline Specification (wood) & Ash (\%) & $\mathrm{pH}_{\mathrm{H} 2 \mathrm{O}}$ & $\mathrm{pH}_{\mathrm{KCl}}$ & $\mathrm{pH}_{\mathrm{CaCl}}$ & General alkalinity (\%) \\
\hline Pear tree & 0.40 & 13.1 & 12.7 & 12.3 & 47.5 \\
Apple tree & 0.46 & 13.4 & 12.9 & 12.5 & 48.1 \\
Aspen & 0.33 & 13.1 & 12.7 & 12.3 & 51.0 \\
Ash & 0.34 & 13.5 & 13.1 & 12.7 & 41.6 \\
Alder & 0.39 & 13.6 & 13.3 & 12.9 & 53.7 \\
Birch & 0.41 & 13.0 & 12.6 & 12.0 & 45.7 \\
Poplaer & 0.62 & 13.5 & 13.1 & 12.5 & 38.9 \\
Hornbeam & 0.47 & 13.7 & 13.4 & 13.0 & 42.5 \\
Pine & 0.38 & 13.0 & 12.6 & 12.1 & 49.2 \\
Common walnut & 0.36 & 9.6 & 9.1 & 8.6 & 38.7 \\
Oak & 0.31 & 13.5 & 13.4 & 12.6 & 49.6 \\
Hazel & 0.42 & 13.4 & 13.0 & 12.5 & 50.6 \\
Bird cherry & 0.51 & 13.7 & 13.2 & 12.7 & 47.8 \\
Spruce & 1.53 & 13.0 & 12.5 & 12.0 & 46.3 \\
\hline Mean & 0.49 & - & - & - & 46.5 \\
Minimum & 0.31 & - & - & - & 38.7 \\
Maximum & 1.53 & - & - & - & 53.7 \\
SD & 0.31 & - & - & - & 4.56 \\
CV (\%) & 0.63 & - & - & 0.10 \\
\hline
\end{tabular}


Table 2. Contents of macronutrients in the wood ashes ( $\mathrm{g} \cdot \mathrm{kg}^{-1}$ D.M.)

\begin{tabular}{|l|c|c|c|c|c|c|c|}
\hline Specification (wood) & $\mathrm{C}_{\text {tot. }}$ & $\mathrm{N}_{\text {tot. }}$ & $\mathrm{P}$ & $\mathrm{K}$ & $\mathrm{Ca}$ & $\mathrm{Mg}$ & $\mathrm{S}$ \\
\hline Pear tree & 148.3 & 4.5 & 23.1 & 108.8 & 305.0 & 32.9 & 13.3 \\
Apple tree & 134.1 & 3.8 & 21.2 & 141.3 & 291.3 & 26.4 & 12.1 \\
Aspen & 210.7 & 11.8 & 28.4 & 166.3 & 285.9 & 29.2 & 18.3 \\
Ash & 135.6 & 4.2 & 13.7 & 133.8 & 325.9 & 37.4 & 18.1 \\
Alder & 160.5 & 3.1 & 20.9 & 106.7 & 312.2 & 40.6 & 26.0 \\
Birch & 132.8 & 1.5 & 38.6 & 108.2 & 408.1 & 92.6 & 33.4 \\
Poplaer & 186.7 & 8.3 & 15.0 & 148.7 & 316.4 & 31.3 & 9.2 \\
Hornbeam & 130.5 & 4.7 & 23.8 & 90.6 & 360.3 & 41.6 & 20.6 \\
Pine & 149.1 & 7.9 & 7.8 & 27.2 & 275.3 & 63.6 & 16.4 \\
Common walnut & 174.8 & 8.1 & 8.8 & 4.5 & 52.9 & 5.1 & 1.4 \\
Oak & 190.3 & 8.7 & 22.9 & 127.7 & 268.8 & 34.9 & 24.3 \\
Hazel & 136.7 & 3.5 & 23.0 & 105.4 & 340.9 & 39.9 & 19.9 \\
Bird cherry & 161.6 & 2.7 & 3.9 & 5.1 & 373.9 & 28.5 & 22.1 \\
Spruce & 189.5 & 8.1 & 24.2 & 92.6 & 318.4 & 47.1 & 19.6 \\
\hline Mean & 160.1 & 5.8 & 19.7 & 97.6 & 302.5 & 39.4 & 18.2 \\
Minimum & 130.5 & 1.5 & 3.9 & 4.5 & 52.9 & 5.1 & 1.4 \\
Maximum & 210.7 & 11.8 & 38.6 & 166.3 & 408.1 & 92.6 & 33.4 \\
SD & 26.3 & 3.0 & 9.1 & 51.2 & 81.7 & 20.0 & 7.7 \\
CV (\%) & 0.16 & 0.5 & 0.5 & 0.5 & 0.3 & 0.5 & 0.4 \\
\hline
\end{tabular}

in a study by Ciesielczuk et al. [2014], obtained from the combustion of oak wood, contained the amounts of $\mathrm{Ca}$ and $\mathrm{Mg}$ that were similar to the results obtained in the author's own study. According to Kołodziej et al. [2016], the ash following the combustion of energy grass (reed canary grass) fertilised with sewage sludges, contained small amounts of calcium and magnesium (Ca-1.42 $\mathrm{gkg}^{-}$ $\left.{ }^{1}, \mathrm{MgO}-0.5 \mathrm{~g} \cdot \mathrm{kg}^{-1}\right)$. Kalembasa [2006] analysed macronutrients and found the greatest amount of calcium was determined in the ash from Virginia fanpetals and Chinese silver grass (Miscanthus sinensis), and the highest amount of potassium was found in the ash from basket willow.

The contents of heavy metals in wood ashes, determined and presented in Table 3, do not restrict the possibilities for their use in agriculture, in accordance with the PN-EN 12944-3 standard [2004]. Large amounts of zinc and manganese indicate the possibility for using the ashes in the cultivation of plants requiring fertilisation with these micronutrients.

Table 3. Contents of heavy metals in the wood ashes (mg.kg-1 D.M.)

\begin{tabular}{|c|c|c|c|c|c|c|c|}
\hline Specification (wood) & $\mathrm{Cd}$ & $\mathrm{Pb}$ & $\mathrm{Zn}$ & $\mathrm{Cu}$ & $\mathrm{Mn}$ & $\mathrm{Ni}$ & $\mathrm{Cr}$ \\
\hline Pear tree & 9.9 & n.d. & 608.0 & 232.9 & 307.5 & 15.3 & 14.4 \\
\hline Apple tree & 9.3 & 1.5 & 353.0 & 581.0 & 137.2 & 3.8 & 10.2 \\
\hline Aspen & 2.4 & n.d. & 614.4 & 119.4 & 1049.7 & 26.2 & 18.2 \\
\hline Ash & 14.0 & 45.8 & 698.1 & 201.7 & 1207.3 & 29.2 & 32.6 \\
\hline Alder & 10.4 & n.d. & 206.2 & 175.3 & 421.5 & 83.2 & 26.3 \\
\hline Birch & 3.3 & n.d. & 252.6 & 209.8 & 919.2 & 91.3 & 48.6 \\
\hline Poplaer & 10.1 & n.d. & 878.6 & 93.7 & 236.5 & 13.4 & 12.3 \\
\hline Hornbeam & 12.5 & 113.3 & 1160.7 & 169.7 & 334.0 & 132.4 & 36.9 \\
\hline Pine & 9.3 & n.d. & 2220.4 & 132.1 & 641.7 & 82.2 & 33.6 \\
\hline Common walnut & 4.4 & 15.2 & 118.9 & 12.0 & 141.3 & 6.4 & 11.2 \\
\hline Oak & 10.4 & n.d. & 592.2 & 197.6 & 840.2 & 32.8 & 27.3 \\
\hline Hazel & 11.9 & 131.0 & 1017.7 & 179.9 & 210.2 & 86.0 & 13.0 \\
\hline Bird cherry & 9.9 & n.d. & 1920.3 & 208.4 & 1012.2 & 5.8 & 59.5 \\
\hline Spruce & 4.2 & n.d. & 2055.7 & 188.7 & 945.7 & 74.4 & 56.8 \\
\hline Mean & 8.7 & 21.9 & 906.9 & 193.0 & 600.3 & 48.7 & 28.6 \\
\hline Minimum & 2.4 & 0.0 & 118.9 & 12.0 & 137.2 & 3.8 & 10.2 \\
\hline Maximum & 14.0 & 131.0 & 2220.4 & 581.0 & 1207.3 & 132.4 & 59.5 \\
\hline SD & 3.6 & 44.4 & 696.9 & 125.7 & 384.2 & 41.4 & 16.9 \\
\hline CV (\%) & 0.4 & 2.0 & 0.8 & 0.6 & 0.6 & 0.8 & 0.6 \\
\hline
\end{tabular}


The ash obtained from the thermal conversion of biomass (oak wood), used in a study by Ciesielczuk et al. [2014], was characterised by the levels of $\mathrm{Zn}, \mathrm{Cu}, \mathrm{Ni}$ and $\mathrm{Cr}$ that were similar to the results obtained in the author's own study. On the other hand, the ash from the combustion of hard coal, used in a study by Antonkiewicz, Lošák [2007] contained smaller amounts of zinc, copper and cadmium as compared to the contents of these elements in wood ashes. The determined amounts of heavy metals in wood ashes were also greater than those determined in the ash obtained following the combustion of Polish waste brown coals [Symanowicz et al. 2013]. The contents of heavy metals in the ashes obtained from the combustion of wood were determined, to a large extent, by the origin of the wood, location and soil conditions under which trees were grown. Ciesielczuk et al. [2011] demonstrated that the acceptable standards for the contents of zinc, cadmium and manganese in a pine ash were exceeded. The proper use of the tested and certified ashes poses no hazard and they can be used in agriculture. This was confirmed by Gibczyńska et al. 2014], who, following the application of ash from biomass at a dose of $1.5 \mathrm{tha}^{-1}$, found no significant increase in the levels of heavy metals in the biomass of spring barley and spring wheat; moreover, the threshold content of heavy metals in the soil was not exceeded.

\section{CONCLUSIONS}

1. Wood ashes are a source of macronutrients for plants. Their contents can be presented in the following series of decreasing values: $\mathrm{Ca}>\mathrm{C}$ $>\mathrm{K}>\mathrm{Mg}>\mathrm{P}>\mathrm{S}>\mathrm{N}$.

2. The content of heavy metals in the analysed ashes was low, and exceeded the acceptable standards for their content in waste materials intended for liming soils.

3. The analysed ashes exhibit good physical and chemical properties. They can be suitable for use in agriculture as a liming agent to be applied on medium and heavy soils.

\section{Acknowledgments}

The results of the research carried out under the research theme No. 315/12/S were financed from the science grant granted by the Ministry of Science and Higher Education.

\section{REFERENCES}

1. Antonkiewicz J., Lošák T. 2007. The effect of hard coal ashes on the amount and quality of maize yield. Part 1. Heavy metals. Acta Universitatis Agriculturae et Silviculturae Mendelianae Brunensis, LV(1), 7-15.

2. Antonkiewicz J. 2014. Effect of fly ashes and sewage sludge on $\mathrm{Fe}, \mathrm{Mn}, \mathrm{Al}$., $\mathrm{Si}$ and Co uptake by grass mixture. Journal of Ecological Engineering, 15(3), 6-13.

3. Antonkiewicz J., Wiśniowska-Kielian B. 2014. Effect of furnace waste and municipal sewage sludge on the $\mathrm{Ca}, \mathrm{Mg}, \mathrm{K}, \mathrm{Na}$ and $\mathrm{P}$ uptake by a mixture of grasses. Annales UMCS s. E, Agricultura, LXIX(2), 57-68. (In Polish)

4. Arvidsson H., Lundkvist H. 2003. Effects of crushed wood ash on soil chemistry in young Norway spruce stands. Forest Ecology Management, 176, 121-132.

5. Baran S., Wójcikowska-Kapusta A., Żukowska G., Bik-Małdzińska M., Wesołowska-Dobruk S. 2015. Influence of sludge-ash composts on some properties of reclaimed land. Archives of Environmental Protection, 41(2), 82-88.

6. Ciesielczuk T., Kulesza G., Nemś A. 2011. Fertilization with biomass ashes as a source of trace elements for soil. Environmental Protection and Natural Resources, 49, 219-227.

7. Ciesielczuk T., Rosik-Dulewska Cz., Kochanowska K. 2014. The influence of biomass ash on the migration of heavy metals in the flooded soil profile - model experiment. Archives of Environmental Protection, 40(4), 3-15.

8. Gibczyńska M., Stankowski S., Hury G., Kuglarz K. 2014. Effects of limestone, ash from biomass and compost use on chemical properties of soil. Soil Science Annual, 65(2), 59-64.

9. Kabata-Pendias A. 2011. Trace elements in soils and plants. CRC Press. 4th ed. Taylor and Francis Group. LLC. 253-254.

10. Kajda-Szcześniak M. 2014. Characteristics of ashes from fireplace. Archives of Waste Management and Environmental Protection, 16(3), 73-78.

11. Kalembasa S., Symanowicz B., Kalembasa D., Malinowska E. 2003. The possibility of receiving and processing of biomass from quick growth rate plants (energetic plants). In: Renewable energy sources. The new insights into sewage sludge, 49, 358-364. (In Polish).

12. Kalembasa D. 2006. The amount and chemical composition of ash obtained from biomass of energy crops. Acta Agrophysica, 7(4), 909-914. (In Polish)

13. Kołodziej B., Stachyra M., Antonkiewicz J., Bielińska E., Wiśniewski J. 2016. The effect of harvest frequecy on yielding and quality of energy raw material 
of reed canary grass grown on minicipal sewage sludge. Biomass and Bioenergy, 85, 363-370.

14. Kowalczyk-Juśko A. 2009. Ash from various energy plants. Proceeding of ECOpole, 3(1), 159-164. (In Polish)

15. Kowalczyk-Juśko A. 2017. The influence of the ash from the biomass on the power boiler pollution. Journal of Ecological Engineering, 18(6), 200-204.

16. Meller E., Bilenda E. 2012. Effect of ashes from biomass combustion on the physicochemical properties of light soils. Energy Policy, 15(3), 287-292. (In Polish)

17. Meller E., Bilenda E. 2013. Effect of ashes fertilization from biomass on yield and uptake of ingredients by common maize. Energy Policy, 16(3), 339-345. (In Polish)

18. Piekarczyk M., Kobierski M., Gałęzewski L. 2017. The influence of the application of barley, wheat and rape straw ash into sandy soil on the changes of soil reaction and the content of available phosphorus, potassium and magnesium. Acta Scientiarum Polonorum Agricultura, 16(3), 139-146.

19. PN - EN 12944-3 2004. Fertilizers and liming materials. Terminology. Part 3. The terms relating to liming materials, 4-5. (In Polish)

20. Regulation of the Minister of the Natural Environment on soil quality standards and earth quality standards, 9 September 2002. Journal of Laws of Poland, No 165, Item 1359. (In Polish)

21. Regulation of the Minister Economy on determining types of fertilizer lime, 19 May 2004. Journal of Laws of Poland, No 130, Item 1384. (In Polish)

22. Regulation of the Minister Agriculture and Rural Development on the implementation of some provisions of the Act on fertilizers and fertilization, 18 July 2008. Journal of Laws of Poland, No 119, Item 765. (In Polish)
23. Regulation Minister Economy on the manner of packing mineral fertilizers, placing information on fertilizer components on these packages, the method of testing mineral fertilizers and types of lime fertilizer dated 8 September 2010 Journal of Laws of Poland, No 183, Item 1229. (In Polish)

24. Regulation Commission (EU) relating to liming materials „EC fertilizer liming agent” No 463/2013 dated 17 May 2013. (In Polish)

25. Regulation of the Minister of the Natural Environment on catalog of wastes dated 9 December 2014. Journal of Laws of Poland, No 112, Item 1923. (In Polish)

26. Statistical yearbook (Central Statistical Office) 2015.

27. Symanowicz B, Kalembasa S. 2004. The content of iron and manganese in brown coals and their ashes. Annuals PZH, 55, 227-231. (In Polish)

28. Symanowicz B, Kalembasa S. 2005. Contents of boron, copper and zinc in brown coals and their ashes. Advances of Agricultural Sciences Problem, 502(2), 853-857. (In Polish)

29. Symanowicz B, Kalembasa S., Jaremko D., Niedbała M. 2013. Polish brown coals waste-potential source of plants nutrients. Annales UMCS s. E Agricultura, LXVIII (4), 21-27. (In Polish)

30. Wacławowicz R. 2011. Agricultural use of ashes from biomass combustion. Seminar. Management of biomass combustion by-products. Warsaw, 181 - 206. (in Polish)

31. Wrzosek J., Gworek B. 2010. Biomass a renewable energy source. Environmental Protection and Natural Resources, 43, 104-116.

32. Xiao R., Chen X., Wang F., Yu G. 2011. The physicochemical properties of different biomass ashes at different ashing temperaturę. Renewable Energy, 36, 244-249. 